\title{
Marmara Denizi’nde Yayılış Gösteren Aurelia aurita Denizanası Türünün Filogenetik Analizi
}

\author{
Meltem GÜNEŞ ${ }^{1}$, Fikriye POLAT $^{2 *}$ \\ ${ }^{1}$ Kocaeli Üniversitesi, Fen Bilimleri Enstitüsü, Biyoloji Bölümü, Kocaeli, Türkiye \\ ${ }^{2}$ Kocaeli Üniversitesi, Eğitim Fakültesi, Matematik ve Fen Bilimleri Eğitimi Bölümü, Kocaeli, Türkiye
}

*Sorumlu Yazar: fikriyepolat@kocaeli.edu.tr

Geliş 24 Ekim 2018; Kabul 08 Mart 2019; Basım 01 Haziran 2019.

Alıntılama: Güneş, M., \& Polat, F. (2019). Marmara Denizi’nde yayılış gösteren Aurelia aurita denizanası türünün filogenetik analizi Acta Aquatica Turcica, 15(2), 163-170 https://doi.org/10.22392/actaquatr.577537

Özet

Çalıșmamızda Marmara Denizi sahillerinde yayılış gösteren Knidliler şubesine ait Aurelia aurita denizanası türü filogenetik olarak incelenmiştir. Bunun için Ekim 2017- Şubat 2018 tarihleri arasında Marmara Denizi'nin kuzey ve güney sahillerinden toplanan denizanası örneklerinden DNA'lar izole edilmiş ve mitokondrial Sitokrom Oksidaz Altünite I (COI), 16S rDNA, nüklear 18S rDNA ve Internal Transcribed Spacer 1 (ITS1) gen bölgeleri Polimeraz Zincir reaksiyonu (PCR) ile amplifiye edilmiş ve ardından dizi analizleri yapılmıştır. Filogenetik analizler GenBank'tan alınan dizilerle birlikte değerlendirilerek gerçekleştirilmiş ve türler arası ilişkiler belirlenmiştir.

Anahtar kelimeler: Aurelia aurita, COI, 16S rDNA, 18S rDNA, ITS1, filogenetik analiz

Phylogenetic Analysis of Jellyfish Species of Aurelia aurita Distributed in the Sea of Marmara

\begin{abstract}
In our study, the species Aurelia aurita jellyfish belonging to the Cnidaria branch distributed in the coasts of the Marmara Sea were examined phylogenetically. For this purpose, DNAs were isolated from the jellyfish samples collected from the northern and southern coasts of the Marmara Sea between October 2017 and February 2018, and mitochondrial Cytochrome Oxidase Subunit I (COI), 16S rDNA, nuclear 18S rDNA and Internal Transcribed Spacer 1 (ITS1) gene regions were amplified by PCR and sequence analysis was performed. Phylogenetic analysis was carried out with the evaluation of the obtained results together with the sequences obtained from GenBank and inter-species relationships were determined.
\end{abstract}

Keywords: Aurelia aurita, COI, 16S rDNA, 18S rDNA, ITS1, phylogenetic analysis

\section{GíRiş}

Dünya üzerindeki tüm denizler ve okyanuslar düşünüldüğünde, 10 binden fazla Knidliler (Cnidaria) türünün yaşadığı keşfedilmiştir (Coll vd., 2010; Appeltans vd., 2012). Bu canlılar gerçek dokuları gelişmiş olan, en basit yapılı çok hücrelilerdir. Çoğu denizlerde, az bir kısmı tatlı sularda bulunan bu şube üyeleri, ayrı ayrı veya koloni halinde yaşamaktadırlar (Tanyolaç ve Tanyolaç, 2000; Bayha vd., 2010).

Türkiye'de denizanası türlerinin içerisinde bulunduğu Scyphozoa (Denizanaları) sınıfını kapsayan Knidliler şubesi, 5 farklı sınıf içermektedir. Denizlerimizde Knidliler şubesine ait Rhizostoma pulmo, Aurelia aurita, Pelagia noctiluca en çok rastlanan türlerdir (Tanyolaç ve Tanyolaç, 2000; Miller ve Harley, 2016; Arai, 1996). Kozmopolit bir tür olan ve genellikle kirli sularda yaşayan, gerek ticari gerekse sağlık açısından zararları bulunan bir denizanası türü olan A. aurita sistematik çalışmaların büyük çoğunluğunda morfolojik yöntemler kullanılarak incelenmiştir. Denizlerdeki yayılışları, toksik etkileri, tomurcuklanma (blooming) gerçekleştirmeleri üzerine pek çok çalışma bulunmaktadır (Kramp, 1961; İşinibilir vd., 2015; Taşer, 2017).

ITS1 geninde ki iki özellik tür tanımlamasına gidilmesinde önemli görülmüştür. Bunlardan birincisi ITS1 genindeki uzunluk varyasyonlarıdır. Bu gen bölgesindeki 240'tan 360 nükleotide değişen uzunlukların olması, kladlardaki farklı türleri ortaya çıkarmada belirleyici olduğu rapor edilmiştir. 
İkinci önemli bir nokta ITS1 de mikrosatellit içeren bölgelerin varlığıdır. A. labiata'da diğer Aurelia türleri ile kıyaslandığında \%10'dan \%40'a varan ITS1 mikrosatellit farklılıkları bulunmuştur (Wesson vd., 1992; Beauchamp vd., 1996; Chen vd., 1996; Odorico vd., 1997). Dawson ve Jacobs (2001) tarafindan belirtildiğine göre \%5'den \%15'e varan bir farklılık ITS1 dizileri arasında türlerin ayrılma düzeyine işaret ediyorsa yaptıkları çalışma Aurelia türünde A. limbata, A. labiata ve A. aurita'ya ek olarak daha önce $A$. aurita olarak tanımlanan altı kriptik türü de tespit etmede kullanilabilecektir.

Aurelia türlerinde COI genindeki \%13'den \%24'e değişen sekans varyasyonu, türler arasındaki farklılıkları ortaya koymada, diğer çok hücrelilerde olduğu gibidir. Böylece dizideki \%10-20'lik bir farklılık, ayrı türleri karşılaştırmak için veri olarak kullanıldığında, COI verileri A. limbata, A. labiata ve $A$. aurita'nın yedi kardeş (sibling) türünde tanımlamayı destekler niteliktedir (Dawson ve Jacobs, 2001)

Denizanası araştırması yapanlar özellikle korunmuş türler arasında morfolojik tür tespiti yapmada zorluklar yaşamaktadır. Sadece birkaç güvenilir taksonomik anahtar bulunmaktadır. DNA sekansı gibi tayin etmeyi kolaylaştıran moleküler teknikler ilerlemesine rağmen GenBank veritabanında denizanası sekansları halâ sınırlı sayıdadır ve çoğunlukla türler 1lıman bölgeler ve Atlantik Okyanusu'ndan gelmektedir (Häussermann vd., 2009). Birkaç tür Pasifik Okyanusu'ndan gelirken (Dawson 2005) Güneydoğu Asya bölgesinden hiç tür tespiti bulunmamıştır. Malakka Boğazı ve Güney Çin Denizi’ni içine alan Malezya Sularında birkaç denizanası kaydı vardır (Rizman-Idid vd., 2016). Türkiye Denizleri'nde GenBank denizanası kaydı Karadeniz-Sinop sahillerinden 2013-2014 yılları arasında olmak üzere 23 adet bildirilmiştir (Keskin ve Atar, 2013), İstanbul Boğazı'nda ise 26 Haziran 2016 tarihli, AY903117 erişim numarası ile 1 adet bulunmaktadır.

$\mathrm{Bu}$ çalışmada Marmara Denizi'nde yayılış gösteren A. aurita'nın COI, 16S rDNA, 18S rDNA ve ITS1 gen bölgelerinin baz dizilişlerini ortaya çıkararak moleküler yönden değerlendirme yapmak amaçlanmıştır.

\section{MATERYAL ve YÖNTEM}

\section{Örneklerin Toplanması}

Çalışmamızda incelemek üzere topladığımız örnekler İzmit Seka Park Sahili (8), İstanbul Yeşilköy Sahili (6), Tekirdağ Kumbağ Sahili (6), Çanakkale Lapseki Sahilinden (8) toplandı. Bu aşamada canlılar atrap yardımıyla yakalanıp, derin bir kap içerisine bir miktar deniz suyu ile birlikte analiz işlemleri yapılmak üzere laboratuvara getirildi.

\section{DNA İzolasyonu ve Polimeraz Zincir Reaksiyonu}

Toplanan denizanası örneklerinin ektoderm tabakalarından doku örnekleri alını Zymo Research Quick DNA Universal Kit (Catalog Nos. D4068 \& D4069) kullanılarak DNA izolasyonları yapıldı.

İzole edilen DNA'lardan mitokondrial COI (Ortman ve diğ., 2010), 16S rDNA (Hamner ve Dowson 2009; Palumbi 1996), 18S rDNA (Bayha ve diğ., 2010) ve ITS1 (Internal Transcribed Spacer I) (Dowson ve Jacops 2001) bölgelerine ait primerler kullanılarak Polimeraz Zincir Reaksiyonu (PCR) (Gradient PCR, SuperCycler: Kyratec) yapıldı. Kullanılan primerler Tablo 1'de, primer bağlanma sıcaklıkları Tablo 2'de görülmektedir. PCR reaksiyon karışımı hazırlamak için 5x FIREPol Master Mix (Solis BioDyne) kullanıldı. Her bir örnek için firma tarafından tavsiye edilen PCR reaksiyon karışımı hazırlandı.

DNA bantlarını tespit etmek için Safe-T staining (etidyum bromide alternatif olarak) kullanılarak TAE tamponunda \%1'lik agaroz jel hazırland. Amplifiye PCR ürünleri yatay jel elektroforez cihazında 100 Voltta 30-45 dakika yürütüldü ve UV translüminatör ile görüntülendi. 
Tablo 1. Mitokondriyal COI, $16 \mathrm{~S}$ rDNA, $18 \mathrm{~S}$ rDNA ve ITS1 bölgelerinin PCR işlemlerinde kullanılan forward ve reverse primerleri

\begin{tabular}{lll}
\hline \hline Primer Bölgesi & Primer Yönü & Primer Dizisi \\
\hline COI & LCO & 5'-GGTCAACAAATCATAAAGATATTGG-3' \\
& HCO & 5'-TAAACTTCAGGGTGACCAAAAAATCA-3' \\
& Forward & 5'-TCGACTGTTTACCAAAAACATAGC-3' \\
16S rDNA & Reverse & 5'-ACGGAATGAACTCAAATCATGTAA-3' \\
& Forward & 5'-AACCTGGTTGATCCTGCCAGT-3' \\
18S rDNA & Reverse & 5'-GATCCTTCTGCAGGTTCACCTAC-3' \\
ITS1 & Forward & 5'-GGTTTCCGTAGGTGAACCTGCGGAAGGATC-3' \\
& Reverse & 5'-CGCACGAGCCGAGTGATCCACCTTAGAAG-3' \\
\hline \hline
\end{tabular}

Tablo 2. Genler ve primerlerin bağlanma sıcaklıkları

\begin{tabular}{lc}
\hline \hline Genler & $\begin{array}{c}\text { Bağlanma } \\
\text { sicaklığı }\left({ }^{\mathbf{0}} \mathbf{C}\right)\end{array}$ \\
\hline COI & 55 \\
16S rDNA & 50 \\
18S rDNA & 48 \\
ITS1 & 60 \\
\hline \hline
\end{tabular}

\section{DNA Sekans Analizi}

PCR ürünleri ExoSAP-IT ${ }^{\mathrm{TM}}$ PCR Product Cleanup Reagent (Thermo Fisher Scientific, USA) kiti prosedürleri kullanılarak BM Labosis tarafindan saflaştırıldı. Saflaştırılan PCR ürünleri COI, 16S rDNA, 18S rDNA ve ITS1'e ait forward ve reverse yönlü primerler ile karıştırılarak dizi analizi gerçekleştirildi. Dizi analizi için Macrogen Hollanda laboratuvarında, ABI 3730XL Sanger dizileme cihazı (Applied Biosystems, Foster City, CA) ve BigDye Terminator v3.1 Cycle Dizileme Kiti kullanılarak yapıldı.

\section{Filogenetik Analiz}

Elde edilen DNA sekansları, Chromas (v.2.6.5.) programı kullanılarak görüntülendi. Chromas üzerinden diziler ayrı ayrı FASTA formatında kaydedildi. Dizilerin forward ve reverse komplement okumaları ClustalW programı ile hizalanarak karşılaştırıldı. Her bir gen bölgesine ait diziler FASTA formatında NCBI Nucleotide BLAST'a yüklendi. NCBI veri bankasında kayıtlı dizilerle benzerlikleri karşılaştırıldı. En çok benzerlik gösteren diziler, benzerlik sıralarına göre GeneBank erişim numaraları ile birlikte filogenetik ağaçta kullanılmak üzere not edildiler (Tablo 3). Çalışılan dört gen bölgesine ait olan tüm diziler ayrı ayrı MEGA (v.7.0) programına yüklenerek modelleme yöntemleri ve mesafeleri belirlendi.

Maksimum Likelihood (ML) metodu, Tamura-Nei Modeli (1993), Bootstrap 1000'de filogenetik ağaçları oluşturuldu. 
Tablo 3. COI gen bölgesi için GenBank’tan (NCBI) alınan sekans verilerine ait erişim numaraları

\begin{tabular}{|c|c|c|}
\hline Genler & Tür & Erişim Numaraları \\
\hline \multirow{4}{*}{ COI } & A. aurita & JQ353727.1 \\
\hline & A. aurita & HМ053519.1 \\
\hline & A. aurita & JQ353728.1 \\
\hline & A. labiata & AY903077.1 \\
\hline \multirow{5}{*}{ 16S rDNA } & A. aurita & JX393252.1 \\
\hline & A. limbata & JX393254.1 \\
\hline & A. labiata & JX393255.1 \\
\hline & C. quinquecirrha & GU300724.2 \\
\hline & S. malayensis & JX393267.1 \\
\hline \multirow{7}{*}{ 18S rDNA } & A. aurita & JX393275.1 \\
\hline & A. limbata & JX393277.1 \\
\hline & A. aurita & AY428815.1 \\
\hline & Poralia sp. & JX393294.1 \\
\hline & N. nomurai & HQ413771.1 \\
\hline & C. pacifica voucher & KY249594.1 \\
\hline & S. malayensis & HM194808.1 \\
\hline \multirow{4}{*}{ ITS1 } & A. aurita & KC767900.1 \\
\hline & C. chinensis & JN202957.1 \\
\hline & P. noctiluca & HМ358359.1 \\
\hline & C. fulgida voucher & HM348774.1 \\
\hline
\end{tabular}

\section{BULGULAR}

Çalışmamızda İzmit Seka Park dışında uzak sahillerden laboratuvara getirilen denizanalarının DNA izolasyonlarında sıkıntılar yaşandı. Ya DNA izole edilemedi ya da kontaminasyondan dolayı balık, alg, böcek ve bakteri DNA'ları izole edildi. Laboratuvarımıza en yakın mesafede olan İzmit Seka Park sahilinden elde ettiğimiz, taze dokudan çalıştığımız en iyi iki örnekle deneylere devam edildi. PCR ile amplifiye edilip sekans1 yapılan SPJ3_COI için MH206614, SPJ5_COI için MH206613 NCBI veri bankasından erişim numaraları alındı. Aynı şekilde 16S rDNA için MH059723 ve MH064432, 18S rDNA için MH059775 ve MH062790, ITS1 gen bölgesi SPJ3 örneği için MH059572 ve SPJ5 örneği için MH062754 numaraları elde edildi. Şekil 1-4'de çalışmamıza ait gen dizileri ile Tablo 3'de görülmekte olan denizanalarına ait dizilerin MEGA (v.7.0) programı ile oluşturulan filogenetik ağaçları görülmektedir. Aynı programda COI geni için en düşük genetik uzaklık 0.004, en yüksek genetik uzakl1k ise 0.295 olarak, baz frekanslar1 ise $f(A)=0.309, f(T)=0.309, f(C)=0.191, f(G)=0.191$ ve $+\mathrm{G}$ (Gamma distribution $)=7.39,+\mathrm{I}=0.56$ bulundu. $16 \mathrm{~S}$ rDNA geni için en düşük genetik uzaklık 0.002 , en yüksek genetik uzaklık ise $0.366^{\prime} \mathrm{d}_{1}$. Baz frekansları $\mathrm{f}(\mathrm{A})=0.354, \mathrm{f}(\mathrm{T})=0.272, \mathrm{f}(\mathrm{C})=0.179$, $\mathrm{f}(\mathrm{G})=0.195$ ve $+\mathrm{G}=0.60,+\mathrm{I}=0.28$ bulundu. $18 \mathrm{~S}$ rDNA için en düşük genetik uzaklık değeri 0.000 iken, en yüksek genetik uzaklık değeri 0.089 olarak bulundu. Baz frekansları $\mathrm{f}(\mathrm{A})=0.272, \mathrm{f}(\mathrm{T})=0.272$, $\mathrm{f}(\mathrm{C})=0.228, \mathrm{f}(\mathrm{G})=0.228$ ve $+\mathrm{G}=0.13,+\mathrm{I}=0.28$ bulundu. ITS1 için en düşük genetik uzaklık 0.004 ve en yüksek genetik uzaklık ise 0.683, baz frekansları ise $\mathrm{f}(\mathrm{A})=0,290, \mathrm{f}(\mathrm{T})=0.290, \mathrm{f}(\mathrm{C})=0.210$, $\mathrm{f}(\mathrm{G})=0.210$ ve $+\mathrm{G}=2.42,+\mathrm{I}=0.33$ bulundu. 


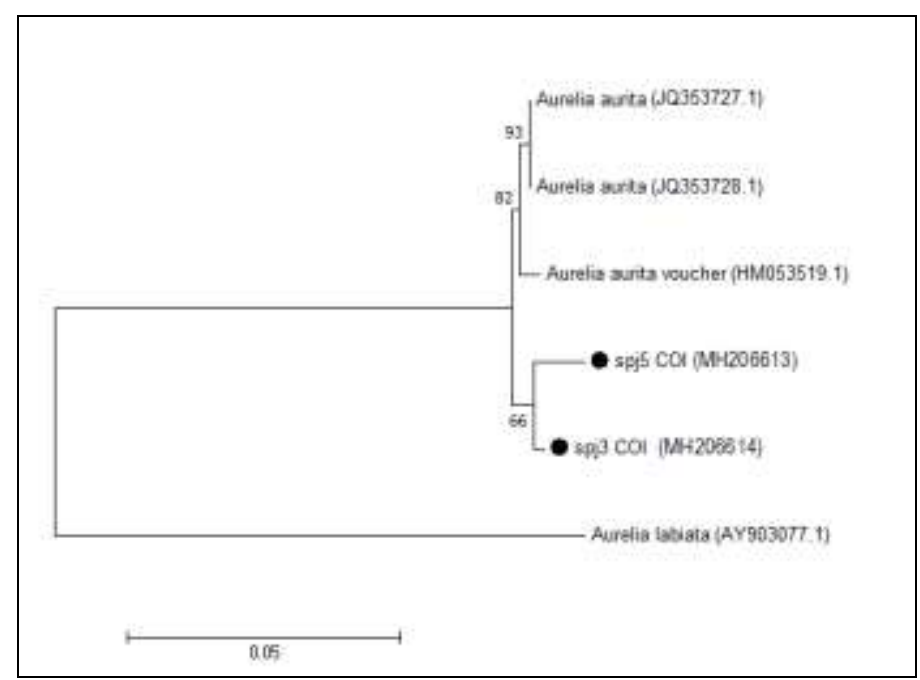

Şekil 1. A. aurita'ya ait COI gen bölgesi için ML metodu ile oluşturulan moleküler filogenetik ağaç

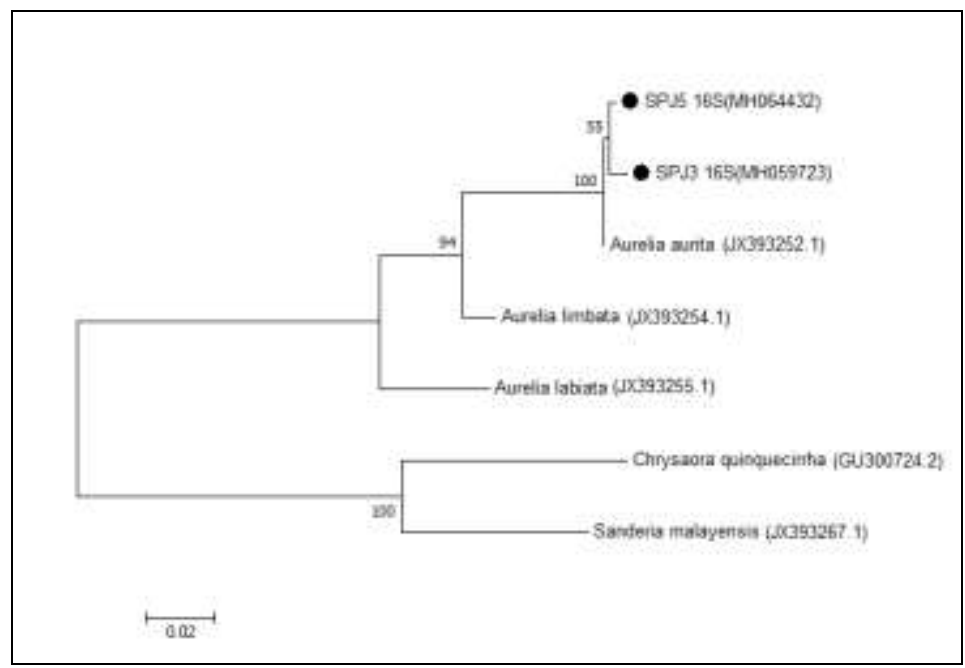

Şekil 2. A. aurita'ya ait $16 \mathrm{~S}$ rDNA gen bölgesi için ML metodu ile oluşturulan moleküler filogenetik ağaç

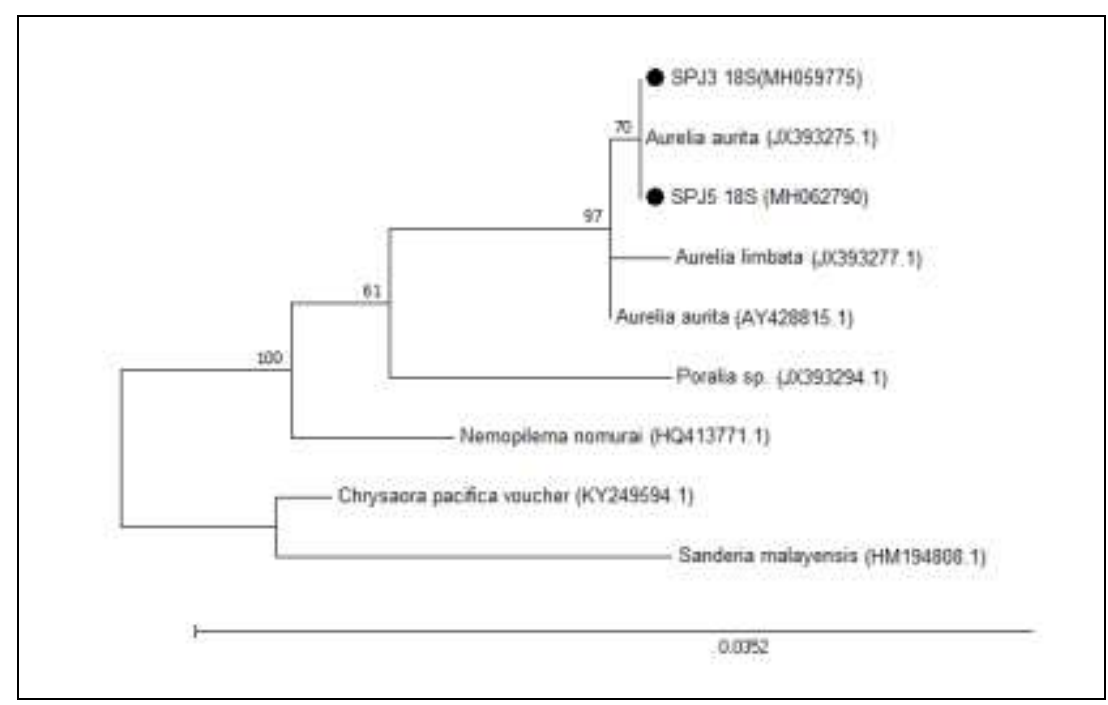

Şekil 3. A. aurita'ya ait $18 \mathrm{~S}$ rDNA gen bölgesi için ML metodu ile oluşturulan moleküler filogenetik ağaç 


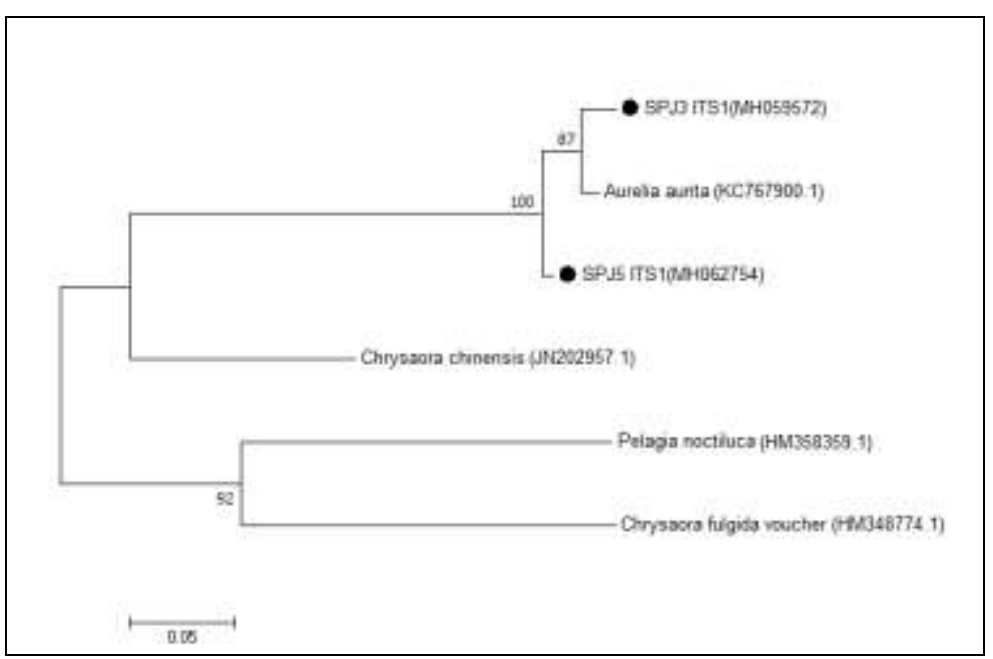

Şekil 4. A. aurita'ya ait ITS1 gen bölgesi için ML metodu ile oluşturulan moleküler fillogenetik ağaç

\section{TARTIŞMA ve SONUÇ}

Türkiye sularında yapılan çalışmalar araştırıldığında Çanakkale Boğazındaki, Scyphomedusae (A. aurita, R. pulmo ve Chrysaora hysoscelld) ve Ctenophora türlerinin (Mnemiopsis leidyi, Pleurobranchia pileus) mevsimsel dağılımları (Çardak, 2002), Karadeniz'de yaşayan $R$. pulmo denizanalarının işlenmesi, protein, karbon, hidrojen, azot, $\mathrm{Ca}, \mathrm{Mg}, \mathrm{Cu}, \mathrm{Fe}, \mathrm{Zn}$ ve Ni miktarlarının bulunması (Özer, 1994) gibi çalışmalar bulunmaktadır. Aurelia bütün denizanaları arasında en çok çalışılmış olmasına rağmen onun taksonomisi ve moleküler karakterizasyonu ile ilgili çok az şey bilinmektedir.

Keskin ve Atar (2013) tarafından Karadeniz-Sinop kıyılarından elde edilen A. aurita örneklerine ait COI gen bölgesi sekans dizilerinin genom veri bankasında kayıtları sağlanmıştır. Marmara Deniz’i sahillerinde yaşayan A. aurita denizanası türü için NCBI genom veri bankasına COI gen bölgesi veri girişleri (MH206614, MH206613) tarafımızca sağlanmış olup ilaveten aynı tür için 16S rDNA (MH059723, MH0644432), 18S rDNA (MH059775, MH062790) ve ITS1 (MH059572, MH062754) DNA barkod genlerine ait sekanslar için de erişim numaraları elde edilmiştir.

COI geninin diğer genlerden üstünlüğü evrensel primer çiftleri kullanılarak çoğaltılabilmesi ve farklı taksonlarda filogenetik sinyale sahip olmasıdır. Üçüncü pozisyondaki kodonları çoğunlukla substitüsyon gösterdiğinden diğer barkod genlerine göre nispeten daha yüksek evrim hızına sahip ve aynı zamanda tür içi farklılı̆̆ ortaya koyabilmektedir (Buclin vd., 2011). MH206614 erişim numaralı SPJ3 örneğimiz, JQ353727.1 erişim numaralı A. aurita ile \%99.1 benzerlik gösterirken A. limbata (AY903189.1) ile \%84.8, A. labiata (AY903077.1) ile \%82.2 benzerlik göstermektedir. Dawson ve Jacobs (2001)'un da belirttikleri gibi COI geninde Aurelia türleri arasında görülen \%13-24 arasında değişen bölgeler çalışmamızdan da görüleceği üzere A. limbata, A. labiata ve A. aurita türleri arasındaki filogenetik ayırımı destekler niteliktedir.

SPJ3 ve SPJ5 örneklerimiz 16S rDNA gen bölgesi açısından incelendiğinde, çalıştığımız türün NCBI BLAST'ta kayitlı A. aurita'larla \%99.3 ve \%99.7 arasında benzerlik oranları olduğu görülmüştür. Bu oranları \%94 ile A. limbata ve \%88.2 ile A. labiata izlemiştir. Poralia sp., $N$. nomurai, $C$. quinquecirrha ve $S$. malayensis ise benzerlik oranları \%75-70 arası bulunmuştur. Türkiye denizlerinde yaşayan A. aurita, R. pulmo ve C. andromeda denizanaları üzerinde Özbalcılar (2012) tarafından yapılan bir çalışmada mitokondrial $16 \mathrm{~S}$ rDNA bölgeleri değerlendirilmiştir. PCR-RFLP tekniği ile denizanası türleri arasında 4 çeşit restriksiyon endonükleaz enzimi (BsurI, AluI, Hin6I, RsaI) kullanarak yaptıkları çalışmada 5 haplotip ortaya çıkarılmış; $R$. pulmo ve A. aurita türlerinin yakın akrabalığ bulunmuştur. Özbalcılar (2012), tarafından yapılan araştırmada 16S rDNA'nın denizanası türleri arasında ayrım gücüne sahip olması yaptığımız çalışma ile parelellik arzetmektedir.

Marmara Denizi ve Karadeniz sahillerinde Doğan (2017), tarafindan Scyphozoa sinıfina ait $A$. aurita ve $R$. pulmo türlerinde ITS1 gen bölgesi kullanılarak filogenetik analiz yapılmış fakat çalışmaya ait örneklerin GeneBank erişim numaralarına ulaşılamamıştır. Yaptığımız çalışma ile Marmara 
Denizi'nde yayılış gösteren A. aurita üzerinde ITS1 geni veri girişi sağlanmış durumdadır. Doğan (2017) tarafindan A. aurita ve $R$. pulmo denizanalarında yapılan çalışmada ITS1 gen bölgelerine ait PCR-jel fotoğrafları incelediğinde farklı nükleotid uzunluklarına sahip bantlar olduğu görülmektedir. Dawson ve Jacobs (2001) ve Batovska vd. (2017) çalışmaları incelendiğinde de, ITS1 gen bölgesinin yüksek varyasyon göstermesi hizalamalarda zorluklar çıkarmasına rağmen denizanası türlerini ortaya çıkarmada, komşu dizileri ile ya da diğer DNA barkod genleri ile birlikte değerlendirilmesinin faydalı olacağını düşünmekteyiz.

SPJ3 (MH059775) ve SPJ5 (MH062790) örneklerimize ait DNA sekanslar1 ile genom veri bankasında kayıtlı (Tablo 3) diğer denizanalarına ait 18S rDNA sekansları hizalandığında benzerlikleri çok yakın olduğu bulunmuştur. Özellikle SPJ3 18S rDNA sekansımız NCBI-BLAST'ta \%100 oranında A. aurita (JX393275.1) ile benzer çıksa da bunu \%99,9 ile A. labiata, \%99,3 ile A. limbata izlemektedir. Elde edilen sonuçlardan da görüleceği üzere denizanalarında 18S rDNA gen bölgesi cins ve tür ayrımında DNA barkodlamada çok ayırıcı değildir. Nitekim 18S rDNA dizisi ağırlıklı olarak evrimsel korunmuş bölgeler içerdiğinden alem, filum, sınıf ve takım seviyesinde filogenetik ilişkileri ortaya çıkarmada kullanılabileceği önerilmektedir (Chalwatzis vd., 1995; Hwang ve Kim, 1999).

Çalışmamıza ait bazı sekans sonuçlarımızı NCBI-BLAST'a yüklediğimizde (kayıt altına almadığımız) midye, balık, alg ve bakteri türleri ile karşılaştık. Çoğunlukla kirli sularda yaşayan denizanası üzerinde moleküler düzeyde çalışma planlayan araştırmacılar için, denizanasından doku örneği almadan önce canlının suyla iyice temizlenmesini, şemsiye kısmından, ektoderm tabakasının hemen altından alınmasını ve taze dokuda çalışılmasını önermekteyiz. Aksi takdirde kontaminasyondan dolayı farklı canlı kalıntılarına ait DNA'ları da izole etmek mümkündür.

Denizlerimizde A. aurita'nın dışında Cassiopea andromeda (Forsskal, 1775), Rhopilema nomadica (Galil, 1990), R. pulmo (Marci, 1778), Cotylorhiza tuberculata (Marci, 1778), C. hysocella (Linnaeus, 1767), Phyllorhiza punctata (von Lendenfeld, 1884) ve P. noctiluca (Forsskal, 1775) denizanası türleri de bulunmaktadır. Ancak literatür incelendiğinde Türkiye denizlerinde yaşayan denizanası türlerine ait birkaç çalışma dışında DNA barkod çalışması bulunmamaktadır (Özbalcılar, 2012; Keskin ve Atar, 2013; Doğan, 2017). İlgi duyan araştırmacılar için yukarıda belirtilen denizanası türlerine ait gen bölgeleri dizilenerek veri bankalarına kayıtları sağlanabilir. Ayrıca Karadeniz, Akdeniz ve Ege Denizi'nde bulunan diğer $A$. aurita'ların da moleküler düzeyde çalışılarak haplotiplerinin belirlenmesi literatüre önemli katkı sağlayacaktır.

Sonuç olarak, bu çalışmada Marmara Denizi sahillerinde yaygın olarak bulunan Aurelia aurita denizanası türü DNA barkodlama tekniği kullanılarak çalışılmıştır. Barkod genleri olarak mitokondrial COI, 16S rDNA, 18S rDNA ve ITS1 gen bölgeleri kullanılmıştır. Ülkemiz sularında yaşayan denizanası türlerine ait barkodlama çalışması yok denecek kadar azdır. Bundan sonraki çalışmalar için gerek denizanaları gerekse diğer aquatik canlılarımız için biyoçeşitliliğimizin moleküler düzeyde ortaya çıkarılması, barkod sistemlerine kayıtlarının sağlanması ve bu alanda literatür açığının kapatılması önerilmektedir.

Teşekkür: *Bu çalışma, yüksek lisans tezinden özetlenmiştir. Çalışma, Kocaeli Üniversitesi Bilimsel Araştırma Projeleri Birimi (KOU BAP-2017-095) tarafindan desteklenmiştir.

\section{KAYNAKLAR}

Appeltans, W., Ahyong, S. T., Anderson, G., Angel, M. V., Artois, T., Bailly, N., Bamber, R., Barber, A., Batsch, I., \& Berta, A. (2012). The Magnitude of Global Marine Species Diversity. Current Biology, 22, 2189-2202.

Arai, M. N. (1996). Functional Biology of Scyphozoa, 1st ed., Chapman and Hall, New York.

Batovska, J., Cogan, N. O., Lynch, S. E., \& Blacket, M. J. (2017). Using Next-Generation Sequencing for DNA Barcoding: Capturing Allelic Variation in ITS2, G3 Genes/Genomes/Genetics, 7, 19-29.

Bayha, K. M., Dawson, M. N., Collins, A. G., Barberitos, M. S., \& Haddock, S. H. D. (2010). Evolutionary relationships among scyphozoan jellyfish families based on complete taxon sampling and phylogenetic analysis of $18 \mathrm{~S}$ and 28S ribosomal DNA, Integrative and Comparative Biology, 50 (3), 436-455.

Beauchamp, K. A., \& Powers, D. A. (1996). Sequence variation of the first internal spacer (ITS1-1) of Ribosomal DNA in ahermatypic corals from California, Molecular marine biology and biotechnology., 5 , 357-362.

Bucklin, A., Steinke, D., \& Blanco-Bercial L. (2011). DNA barcoding of marine metazoa. Annual Reviews of Marine Science. 3, 471-508. 
Chalwatzis, N., Bauer, A., Stetzer, E., Kinzelbach, R., \& Zimmermann, F. K. (1995). Strongly expanded $18 \mathrm{~S}$ rRNA genes correlated with a peculiar morphology in the insect order of Strepsiptera, Zoology, 98, 115126.

Chen, C. A., Willis, B. L., \& Miller, D. J. (1996). Systematic relationships between tropical corallimopharians (Cnidaria: Anthozoa: Corallimorpharia): utility of the 5.8S and internal transcribed spacer (ITS) regions of the rDNA transcription unit, Bulletin of Marine Science, 59, 196-208.

Coll, M., Piroddi, C., Steenbeek, J., Kaschner, K., Lasram, F. B. R., Aguzzi, J., Ballesteros, E., Bianchi, C. N., Corbera, J., \& Dailianis, T. (2010). The biodiversity of the Mediterranean Sea: estimates, patterns and threads, PLoS, 5,11842.

Çardak, M. (2002). Çanakkale Boğazı, Nara Burnu civarındaki scyphozoa ve ctenophora türleri ile bunların bölgedeki dağılımlarının araştırılması, Yüksek Lisans Tezi, Çanakkale Onsekiz Mart Üniversitesi, Fen Bilimleri Enstitüsü, ref. no: 121545.

Dawson, M. N., \& Jacobs, D. K. (2001). Molecular evidence for cryptic species of Aurelia aurita (Cnidaria, Scyphozoa), The Biological Bulletin, 200, 92-96.

Dawson, M. N. (2005).Incipient speciation of Catostylus mosaicus (Scyphozoa, Rhizostomeae, Catostylidae), comparative phylogeography and biogeography in southeastern Australia, Journal of Biogeography 32, 515-533.

Doğan, O. (2017). Türkiye Kıyılarında Dağılım Gösteren Scyphozoa Sınıfına Ait Bazı Türlerin Moleküler Filogenisi, Yüksek Lisans Tezi, İstanbul Üniversitesi, Fen Bilimleri Enstitüsü, İstanbul, ref. no: 462931.

Hamner, W.M., Dawson, M.N. (2009). A systematic review of the evolution of jellyfish blooms: advantageous aggregations and adaptive assemblages. Hydrobiologia, 616, 161-191.

Häussermann, V., Dawson, M.N., Försterra, G.( 2009). First record of the moon jellyfish, Aurelia for Chile. Spixiana 32(1),3-7.

Hwang, U. W., Kim, W. (1999). General properties and phylogenetic utilities of nuclear ribosomal DNA and mitochondrial DNA commonly used in molecular systematics, The Korean Journal of Parasitology, 37 (4), 215

İşinibilir, M., Yilmaz, I. N., \& Demirel, N. (2015). New records of jellyfish species in the Marmara Sea, Italian Journal of Zoology, 82, 425-429.

Keskin, E., \& Atar, H. H. (2013). DNA barcoding commercially important aquatic invertebrates of Turkey, Mitochondrial DNA The Journal of DNA Mapping, Sequencing, and Analysis, 24 (4), 440-450.

Kramp, P. (1961). Sinopsis of the medusae of the world, J. Mar. Biol. Assoc., 40, 1-469.

Miller, S. A., Harley, J. P. (2016). Zoology, 10th ed., McGraw Hill, New York, 2016.

Odorico, D. M., \& Miller, D. J. (1997). Variation in the ribosomal internal trandcribed spacers and 5.8S rDNA among five species of acropora (Bnidaria: Scleractinia): patterns of variation consistent with reticulate evolution, Mol. Biol. Evol., 14, 465-473.

Ortman, B. D., Bucklin, A., Pages, F., \& Youngbluth, M. (2010). DNA barcoding the Medusozoa using mtCOI. Deep-Sea Res Pt II. 57, 2148-2156.

Özbalcılar, B. (2012). Türkiye denizlerinde bulunan Akdeniz ve İndo-Pasifik kökenli denizanaları'nın filogenetiği, Yüksek Lisans Tezi, Mustafa Kemal Üniversitesi, Fen Bilimleri Enstitüsü, Hatay, ref. no:329548.

Özer, N. P. (1994). Rhizostoma pulmo (Macri, 1778) Denizanasının İşleme ve Değerlendirme Yöntemlerinin Karşılaştırılması, Doktora Tezi, Karadeniz Teknik Üniversitesi, Fen Bilimleri Enstitüsü, ref. no: 33737.

Palumbi, S. R. (1996). Nucleic acids II: The polymerase chain reaction. In Molecular systematics. Edited by Hillis DM, Moritz C, Mable BK. Sinauer Associates, Inc.; 205-247.

Rizman-Idid, M., Farrah-Azwa, A.B., \& Chong, V.C. (2016). Preliminary Taxonomic Survey and Molecular Documentation of Jellyfish Species (Cnidaria: Scyphozoa and Cubozoa) in Malaysia. Zoological Studies, 55(35), 1-19 doi:10.6620/ZS.2016.55-35

Tanyolaç, J., \& Tanyolaç, T. (2000). Genel Zooloji, 6. Baskı, Hatiboğlu Yayınevi, Ankara.

Taşer, Y. (2017). Denizanalarının farklı alanlarda değerlendirilmesi (Cnidaria: Coelenterata), Yüksek Lisans Tezi, Katip Çelebi Üniversitesi, Fen Bilimleri Enstitüsü, İzmir, ref. no: 459006.

Wesson, D. M., Porter, C. H., \& Colling, F. H. (1992). Sequence and secondary structure comparisons of ITS rDNA in mosquitoes (Diptera: Culicidae), Molecular phylogenetics and evolution, 1, 253-269. 